\title{
Two decades of successes and failures in controlling the transmission of HIV through injecting drug use in England and Wales, 1990 to 2011
}

V D Hope ${ }^{1,2}$, R J Harris (ross.harris@phe.gov.uk) ${ }^{1}$, De Angelis ${ }^{3}$, S Croxford $^{1}$, A Marongiu $^{1}$, J V Parry $^{1}$, F Ncube ${ }^{1}$

1. Centre for Infectious Disease Surveillance and Control, Public Health England, London, United Kingdom

2. Centre for Research on Drugs and Health Behaviour, London School of Hygiene and Tropical Medicine, London, United Kingdom

3. MRC Biostatistics Unit, Institute of Public Health, University Forvie Site, Cambridge, United Kingdom

Citation style for this article:

Hope VD, Harris RJ, De Angelis D, Croxford S, Marongiu A, Parry JV, Ncube F. Two decades of successes and failures in controlling the transmission of HIV through injecting drug use in England and Wales, 1990 to 2011. Euro Surveill. 2014;19(14):pii=20762. Available online: http://www.eurosurveillance.org/ViewArticle.

aspx?Articleld $=20762$

Article submitted on 08 March 2013 / published on 10 April 2014

Responses to injecting drug use have changed focus over the last 20 years. Prevalence and incidence of human immunodeficiency virus (HIV) among people who inject drugs (PWID) in England and Wales were examined in relation to these changes. A voluntary unlinked-anonymous surveillance study obtained a biological sample and questionnaire data from PWID through annual surveys since 1990. Prevalence and incidence trends were estimated via generalised linear models, and compared with a policy time-line. Overall HIV prevalence among 38,539 participations was $1.15 \%$. Prevalence was highest among those who started injecting before 1985; throughout the 1990s, prevalence fell in this group and was stable among those who started injecting later. Prevalence was higher in 2005 than 2000 (odds ratio: 3.56 (95\% confidence interval (Cl) 1.40-9.03) in London, 3.40 ( $95 \%$ $\mathrm{Cl}$ 2.31-5.02) elsewhere). Estimated HIV incidence peaked twice, around 1983 and 2005. HIV was an important focus of policy concerning PWID from 1984 until 1998. This focus shifted at a time when drug use and risk were changing. The increased incidence in 2005 cannot be ascribed to the policy changes, but these appeared to be temporally aligned. Policy related to PWID should be continually reviewed to ensure rapid responses to increased risk.

\section{Introduction}

The vulnerability of people who inject drugs (PWID) to blood borne-infection was recognised early in the human immunodeficiency virus (HIV) pandemic, with the rapid spread resulting in high prevalence among PWID in many parts of the world [1-4]. However, a number of countries, including the United Kingdom (UK), have reported a low HIV prevalence [5-7] among PWID, which has been attributed to the timely introduction of comprehensive harm reduction measures, including needle and syringe programmes (NSPs) and opiate substitution therapy (OST) [8]. In the UK such measures were promptly introduced in the mid-1980s in response to substantial HIV outbreaks among PWID in two Scottish cities $[9,10]$.

In England and Wales, HIV prevalence among PWID has been monitored in a consistent way since 1990 $[11,12]$, and reveals a consistently higher HIV prevalence among PWID in London compared to elsewhere $[11,13]$. Throughout the course of the HIV epidemic in England and Wales policy related to both injecting drug use (IDU) and HIV have changed, as have the patterns of drug use (Table 1). This has resulted in changes to the extent and types of responses over time: broadly, policy related to IDU shifted from a focus on preventing HIV infection in the late 1980 s and early 1990 s to a focus on criminal justice issues at the end of the 1990s, with an increased emphasis on harm reduction from 2006 onwards (Table 1).

This paper examines trends in HIV prevalence among PWID in England and Wales between 1990 and 2011, and considers these in the context of the changes in policy and responses.

\section{Methods}

\section{Survey of PWID}

In England and Wales PWID have been recruited into an annual voluntary unlinked-anonymous survey since 1990, the methodological details of which have been published previously [11]. Briefly, services providing harm reduction or addiction treatment interventions to people who use drugs throughout England and Wales invite clients who have ever injected to participate in annual surveys [14]. Those who agree provide an oral fluid sample or, since 2009, a dried blood spot (DBS) sample and self-complete a brief questionnaire. Agency selection reflects the range of services provided to PWID as well as reported geographic variations in IDU, with the agency selection reviewed regularly. 
TABLE 1

Timeline of public health responses and policies on HIV and injecting drug use, England and Wales, 1981-2011

\begin{tabular}{|c|c|}
\hline Year & Event \\
\hline 1981 & First AIDS cases diagnosed in the US [59], and first case recognised in the UK [60]. \\
\hline 1982 & - \\
\hline 1983 & HIV (LAV) first isolated [61]. \\
\hline 1984 & Laboratory test for HIV developed [62]. Preliminary HIV prevalence data [63]. First case of AIDS in PWID in the UK [9]. \\
\hline 1985 & $\begin{array}{l}\text { Sample of PWID in England and Wales suggests ca } 2.5 \% \text { prevalence [64]. } \\
\text { Laboratory testing for HIV rolled out and HIV (HTLV-III) screening of UK blood donations began [65]. }\end{array}$ \\
\hline 1986 & $\begin{array}{l}\text { Paper published suggesting HIV prevalence among PWID in Edinburgh and Dundee could be as high as } 85 \% \text { [10]. } \\
\text { First clinical trials of anti-retroviral drug (zidovudine) showing benefit [66]. } \\
\text { UK's first NSP opened in Peterborough, Liverpool and London [9]. }\end{array}$ \\
\hline 1987 & $\begin{array}{l}\text { Pilot study of NSP started with } 15 \text { sites across the UK (13 in England) [9]. } \\
\text { AIDS Control Act required returns from all local areas including on their provision of preventive services [67]. } \\
\text { First description of use of saliva for HIV screening [68]. }\end{array}$ \\
\hline 1988 & $\begin{array}{l}\text { Advisory Council on the Misuse of Drugs recommended actions to reduce HIV risk behaviours among PWID, later termed the } \\
\text { Harm reduction approach [27]. } \\
\text { Expansion of NSP and OST provision started, continuing into the } 1990 \text { s [9]. }\end{array}$ \\
\hline 1989 & Evaluation of UK NSP pilot published [28]. \\
\hline 1990 & Sero-behavioural monitoring of HIV in PWID started in England and Wales [14]. \\
\hline 1991 & - \\
\hline 1992 & The new national health strategy Health of the Nation, included a target to reduce needle and syringe sharing [30]. \\
\hline 1993 & $\begin{array}{l}\text { Advisory Council on the Misuse of Drugs second report on HIV among PWID recommended a 'broad based public health } \\
\text { approach' with targeted interventions such as NSPs and substitute prescribing [69]. } \\
\text { National HIV prevalence among PWID (1990-91) between } 1 \text { and } 2 \% \text {, but higher in London (ca 4\%) [14]. }\end{array}$ \\
\hline 1994 & - \\
\hline 1995 & $\begin{array}{l}\text { Tackling drugs together a strategy for England published, covers many topics and specifically mentions HIV [29]. } \\
\text { First study published on hepatitis C prevalence among PWID in the UK indicates that this is high [70]. }\end{array}$ \\
\hline 1996 & Introduction of HAART [71]. \\
\hline 1997 & Prevalence of HIV among PWID declined to less than $1 \%$ [72]. \\
\hline 1998 & $\begin{array}{l}\text { New UK Drugs Strategy published; focusing on drug-related crime through treating and preventing addiction. Infections } \\
\text { among PWID only mentioned briefly [73]. }\end{array}$ \\
\hline 1999 & $\begin{array}{l}\text { National hepatitis C prevalence among PWID published; this at } 35 \% \text { was much lower than suggested by earlier studies } \\
{[33,34] \text {. Prevalence of HIV among PWID stable [33]. First report on an increase in the level of needle/syringe sharing [33]. }} \\
\text { Increased crack cocaine use and injection from the end of the } 1990 \text { [ [74]; associated with more frequent injection and } \\
\text { greater risk [13]. }\end{array}$ \\
\hline 2000 & $\begin{array}{l}\text { Outbreak of Clostridium novyi infection in PWID. Increase in a range of severe bacterial infections among PWID seen over } \\
\text { the next few years }[25,50] \text {. } \\
\text { Welsh Strategy on Drug Use launched (Wales) [75]. }\end{array}$ \\
\hline 2001 & $\begin{array}{l}\text { National Sexual Health and HIV Strategy launched, focusing on sexual transmission [35]. } \\
\text { National Treatment Agency for Substance Misuse (England) established, supported by increased spending on the treatment } \\
\text { of addiction [76]. }\end{array}$ \\
\hline 2002 & $\begin{array}{l}\text { Models of Care, a national framework for drug services in England published, little on infections [36]. } \\
\text { Drug Strategy updated, infections among PWID still only mentioned briefly [37]. } \\
\text { Paper published highlighting sustained increase in needle/syringe sharing [12]. }\end{array}$ \\
\hline 2003 & First annual UK report on infections among PWID highlighted concerns about rising levels of infections including HIV [44]. \\
\hline 2004 & $\begin{array}{l}\text { Hepatitis C Action Plan launched (England), with target to reduce transmission among PWID [77]. } \\
\text { Research among PWID indicated that they see HCV as 'inevitable' [53]. }\end{array}$ \\
\hline 2005 & Paper published indicating HIV prevalence has been increasing among PWID [11]. \\
\hline 2006 & $\begin{array}{l}\text { Fourth annual report on infections among PWID in the UK, highlighting continuing increase in levels of blood-borne viruses } \\
\text { [26]. } \\
\text { Models of Care updated, greater focus on infections (England) [45]. }\end{array}$ \\
\hline 2007 & Drug Related Harm Action Plan, leading to reinvigoration of harm reduction approaches [46]. \\
\hline 2008 & $\begin{array}{l}\text { Harm Reduction Works information campaign launched [48]. } \\
\text { A new Drug Strategy launched (England), focusing on reducing crime and drug use, infections among PWID only mentioned } \\
\text { briefly [47]. }\end{array}$ \\
\hline 2009 & NICE Guidance on provision of NSP [49]. \\
\hline 2010 & $\begin{array}{l}\text { A new national Drug Strategy launched, focussing on recovery from addiction, with infections among PWID only mentioned } \\
\text { briefly [51]. }\end{array}$ \\
\hline 2011 & - \\
\hline
\end{tabular}

AIDS: acquired immunodeficiency syndrome; HAART: highly active antiretroviral therapy; HCV: hepatitis C virus; HIV: human

immunodeficiency virus; HTLV: human T-lymphotropic virus type; LAV: lymphadenopathy-associated virus; NICE: National Institute for Health and Care Excellence; NSP: needle and syringe programme; OST: opiate substitution therapy; PWID: people who inject drugs; UK: United Kingdom; US: United States.

Hyphens (-) indicate no notable events or policy changes for that year. 
Oral fluid specimens have been collected using the OraSure device (OraSure Technologies Inc, US) since 1998; before that the Salivette (Starstedt Ltd, Leicester, UK) was used. OraSures were introduced in 1998 to optimise the detection of antibodies to hepatitis C virus (HCV) [15]. Oral fluid specimens were tested for antibodies to HIV (anti-HIV) by an IgG antibody capture ELISA (GACELISA) HIV 1+2 (Abbott Murex Diagnostics Ltd, UK) and, since production of this kit stopped in 2004, by an in-house GACELISA with similar performance. Reactive specimens underwent further testing according to a proven algorithm that included a second ELISA and Western blot, for which sensitivity and specificity approached $100 \%$ [16].

In $2009,16 \%$ of samples were DBS, rising to $67 \%$ in 2010 and $100 \%$ subsequently. For DBS, eluates were prepared and screened by the same laboratory using the GACELISA HIV 1+2; reactive specimens were subject to Western blot analysis to determine the specificity of the reaction.

\section{Analysis}

Those who had injected drugs in the four weeks before participation in the survey where included in the analyses. Trends in HIV prevalence were examined via logistic regression. As previous analysis had indicated a higher prevalence and different patterns in London compared with elsewhere [11], analyses were performed separately for London and the rest of England and Wales.

Demographics of the population of PWID have changed over time [17]; therefore, injecting duration, age and sex were controlled for to determine underlying temporal trends. We also aimed to estimate interactions between survey year and injecting duration, corresponding to a cohort effect for the year injecting started. Specifying a model that is flexible enough to adequately model changes in prevalence by time and injecting duration is difficult due to the small number of observed cases. Models with individual effects for each survey year will fit the data well, but require a high number of parameters and do not exploit any underlying trends in the data because prevalence in each year is assumed to be independent of preceding years. We therefore employed polynomial models that incorporate quadratic and higher powers of variables to fit non-linear trends, similar to Sweeting et al. [18].

We used a systematic approach to model selection, with models assessed via the Akaike Information Criteria (AIC); this statistic balancing model fit with parsimony. We focussed on polynomial models, considering polynomials up to degree 5 for time and injecting duration, quadratic effects for age and, sex and potential interactions between them. A complete search of all possible interactions (which may be the same as or lower than the degree of main effects) is not possible as the number of possible combinations is too large. Therefore we undertook a full search of possible interactions (up to degree 5) between time and injecting duration effects, but only up to degree 2 for their interactions with age and sex. Given a large set of candidate models, there will inevitably be uncertainty in the model selection process. The selected model may not provide the best match to the true underlying trend, and subsequent inferences do not account for the uncertainty in model selection. We therefore calculated model-averaged estimates [19] to assess the robustness of the prevalence estimates obtained from the selected model. Briefly, the method provides a weighted average for prevalence estimates, with weights based on the AIC score (better scoring models have more influence) and accounting for additional between-model variability in confidence intervals. The idea was that if the final model was not dissimilar to the model-averaged results, we could be confident that features of the estimated temporal trend were not merely due to a particular parameterisation.

\section{Incidence}

A variety of applications have been used to estimate incidence according to age or time from sero-prevalence surveys [20]. When surveys are available from multiple time points, both age and time effects may be estimated. Ades and Nokes define $h_{A}(a)$, a function for incidence at age $a$, and $h_{T}(t)$, a function for timespecific incidence at time $t$; and relate them to the proportion susceptible, $q(a, t)$ [21]. Integrating exposure between the date of birth, $t-a$, and the survey date $t$, via the age- and time-specific components, we have:

$$
q(a, t)=\exp \left[-\int_{0}^{a} h(z, t-a+z) d z\right]
$$

In the context of HIV in PWID, it is assumed that most infections will have occurred via injecting; therefore 'age' in this context corresponds to injecting duration. Although we refer to the at-risk period as injecting duration is in fact time since first injected, and may include periods of cessation; in the absence of information on this we assume constant exposure throughout, averaging over any periods of non-injecting. We modelled incidence in a Bayesian framework, replacing the integration above with summation, as data are discrete. Point estimates are taken as the median of the posterior distributions, with 2.5 th and $97.5^{\text {th }}$ percentiles forming a $95 \%$ credible interval, the Bayesian equivalent of a confidence interval. Both the time effect, $h_{T}(t)$ and injecting duration effect $h_{A}(a)$ were modelled using a random walk function in order to give a flexible shape, but capitalise on patterns in the data [22]. Due to the low prevalence of HIV and the inherent uncertainty of estimating incidence from prevalence, incidence of HCV was simultaneously modelled (using data from 1998 when anti-HCV testing was introduced into the survey), with independent functions for $h_{T}(t)$ 
Participant characteristics and HIV prevalence by year, injecting duration, age and sex, London versus the rest of England and Wales, 1990-2011 ( $\mathrm{n}=38,539)$

\begin{tabular}{|c|c|c|c|c|c|c|}
\hline & \multicolumn{3}{|c|}{ London } & \multicolumn{3}{|c|}{ Rest of England and Wales } \\
\hline & $\mathrm{n}$ & Anti-HIV-positive & $\%$ & $\mathrm{n}$ & Anti-HIV-positive & $\%$ \\
\hline \multicolumn{7}{|l|}{ Age } \\
\hline $15-24$ & 775 & 11 & $1.42 \%$ & 8,381 & 22 & $0.26 \%$ \\
\hline $25-29$ & 1,490 & 55 & $3.69 \%$ & 8,585 & 44 & $0.51 \%$ \\
\hline $30-34$ & 1,714 & 75 & $4.38 \%$ & 6,895 & 33 & $0.48 \%$ \\
\hline$\geq 35$ & 2,913 & 129 & $4.43 \%$ & 7,786 & 76 & $0.98 \%$ \\
\hline \multicolumn{7}{|l|}{ Sex } \\
\hline Male & 4,948 & 210 & $4.24 \%$ & 24,437 & 141 & $0.58 \%$ \\
\hline Female & 1,944 & 60 & $3.09 \%$ & 7,210 & 34 & $0.47 \%$ \\
\hline \multicolumn{7}{|c|}{ Injecting duration (years since first injected) } \\
\hline $0-2$ & 961 & 12 & $1.25 \%$ & 6,825 & 21 & $0.31 \%$ \\
\hline 3-5 & 975 & 10 & $1.03 \%$ & 6,292 & 14 & $0.22 \%$ \\
\hline $6-9$ & 1,249 & 31 & $2.48 \%$ & 6,526 & 25 & $0.38 \%$ \\
\hline $10-15$ & 1,403 & 78 & $5.56 \%$ & 5,961 & 42 & $0.70 \%$ \\
\hline$>15$ & 2,304 & 139 & $6.03 \%$ & 6,043 & 73 & $1.21 \%$ \\
\hline \multicolumn{7}{|c|}{ Survey year } \\
\hline $1990-95$ & 1,943 & 92 & $4.73 \%$ & 7,374 & 41 & $0.56 \%$ \\
\hline $1996-99$ & 1,729 & 36 & $2.08 \%$ & 6,857 & 23 & $0.34 \%$ \\
\hline $2000-03$ & 1,394 & 56 & $4.02 \%$ & 6,039 & 12 & $0.20 \%$ \\
\hline $2004-07$ & 1,149 & 49 & $4.26 \%$ & 6,000 & 52 & $0.87 \%$ \\
\hline $2008-11$ & 677 & 37 & $5.47 \%$ & 5,377 & 47 & $0.87 \%$ \\
\hline Total & 6,892 & 270 & $3.92 \%$ & 31,647 & 175 & $0.55 \%$ \\
\hline
\end{tabular}

HIV: human immunodeficiency virus.

but a shared injecting duration effect, $h_{A}(a)$, which had the effect of a relative risk for subsequent injecting durations following the first year. This increased the power to estimate the injecting risk function, based on the assumption that risk of infection was proportional for all blood-borne infections throughout an injecting career, with risky practices corresponding to a general increase in risk of infection with both HIV and HCV.

\section{Results}

Between 1990 and 2011, 40,261 specimens were collected in England and Wales from PWID aged 15 to 59 years who had injected in the previous four weeks. Due to missing data on sex $(n=198)$ and/or injecting duration $(n=1,541), 38,539$ were included in the analyses. Of these, 6,892 (17.9\%) were recruited in London, 29,385 (76.3\%) were male, 9,156 (23.8\%) were younger than 25 years (median age: 30 years), and the median number time since starting to inject was eight years (range: $0-45$ years). The overall anti-HIV prevalence over the 22 -year period was $1.15 \%(445 / 38,539)$. Table 2 shows the characteristics and HIV prevalence by year, injecting duration, age and sex for London and rest of England and Wales. HIV prevalence increased with age, although this was confounded with injecting duration, and was higher in London than elsewhere for all subgroups. For both regions, prevalence decreased before increasing in the most recent years, although patterns were different between London and elsewhere $(p=0.004)$.

A number of logistic regression models for HIV prevalence had similar AIC scores, but there were consistent features in the highest-scoring models: for the rest of England and Wales, most included fourth- or fifth-order terms for time (representing fairly complex shapes), third-order for injecting duration and secondor third- order interactions between them. For London, time and injecting duration terms were both up to fifth power for most models, and again, with significant interactions. As the best scoring models tended to differ mainly in the parameterisation of age, sex and higher order interactions, which are relatively weak, model-averaged results were fairly similar to the best scoring model (further details are available from the authors on request). Parameter estimates for the final models are shown in Table 3. 
TABLE 3

Final models for HIV prevalence in London versus the rest of England and Wales, 1990-2011 (n=38,539)

\begin{tabular}{|c|c|c|c|c|c|c|}
\hline & \multicolumn{3}{|c|}{ London } & \multicolumn{3}{|c|}{ Rest of England and Wales } \\
\hline & Odds ratio & $95 \% \mathrm{Cl}$ & $\mathrm{p}$ value & Odds ratio & $95 \% \mathrm{Cl}$ & $p$ value \\
\hline \multicolumn{7}{|l|}{ Year } \\
\hline Year & 1.57 & $0.78-3.17$ & 0.207 & 2.11 & $1.36-3.26$ & 0.001 \\
\hline Year $^{2}$ & 3.59 & $1.76-7.33$ & $<0.001$ & 3.17 & $1.64-6.16$ & 0.001 \\
\hline Year $^{3}$ & 0.46 & $0.21-1.01$ & 0.052 & 0.82 & $0.68-1.00$ & 0.047 \\
\hline Year $^{4}$ & 0.68 & $0.52-0.88$ & 0.004 & 0.79 & $0.64-0.96$ & 0.020 \\
\hline Year $^{5}$ & 1.23 & $1.00-1.50$ & 0.049 & - & - & - \\
\hline \multicolumn{7}{|c|}{ Injecting duration } \\
\hline Inj dur & 7.01 & $2.74-17.95$ & $<0.001$ & 1.36 & $0.92-2.03$ & 0.126 \\
\hline Inj dur ${ }^{2}$ & 0.49 & $0.19-1.24$ & 0.131 & 1.76 & $1.18-2.63$ & 0.006 \\
\hline Inj dur ${ }^{3}$ & 0.94 & $0.46-1.94$ & 0.869 & 0.83 & $0.73-0.93$ & 0.001 \\
\hline Inj dur 4 & 1.38 & $0.86-2.19$ & 0.180 & - & - & - \\
\hline Inj dur ${ }^{5}$ & 0.86 & $0.76-0.96$ & 0.010 & - & - & - \\
\hline \multicolumn{7}{|l|}{ Age } \\
\hline Age & 0.67 & $0.53-0.85$ & 0.001 & 1.47 & $1.03-2.11$ & 0.036 \\
\hline Age $^{2}$ & 0.88 & $0.75-1.04$ & 0.127 & - & - & - \\
\hline \multicolumn{7}{|l|}{ Sex } \\
\hline Female & 0.85 & $0.63-1.15$ & 0.290 & 1.03 & $0.70-1.51$ & 0.882 \\
\hline \multicolumn{7}{|c|}{ Year $\times$ injecting duration } \\
\hline Year $\times$ Inj dur & 0.23 & $0.05-1.11$ & 0.068 & 0.47 & $0.34-0.65$ & $<0.001$ \\
\hline Year $\times \operatorname{lnj}$ dur ${ }^{2}$ & 2.05 & $0.69-6.04$ & 0.195 & 1.15 & $0.92-1.45$ & 0.220 \\
\hline Year $\times$ Inj dur ${ }^{3}$ & 1.78 & $0.62-5.07$ & 0.283 & 0.99 & $0.94-1.04$ & 0.787 \\
\hline Year $\times$ Inj dur ${ }^{4}$ & 0.78 & $0.49,-1.25$ & 0.300 & - & - & - \\
\hline Year $^{2} \times \operatorname{Inj}$ dur & 0.55 & $0.11-2.76$ & 0.470 & 1.71 & $1.23-2.37$ & 0.001 \\
\hline Year $^{2} \times \operatorname{lnj}$ dur ${ }^{2}$ & 0.16 & $0.03-0.77$ & 0.023 & 0.61 & $0.46-0.80$ & $<0.001$ \\
\hline Year $^{2} \times \operatorname{Inj}$ dur ${ }^{3}$ & 0.48 & $0.13-1.76$ & 0.268 & 1.14 & $1.07-1.22$ & $<0.001$ \\
\hline Year $^{2} \times \operatorname{Inj}$ dur ${ }^{4}$ & 2.38 & $1.14-4.97$ & 0.021 & - & - & - \\
\hline Year $^{3} \times$ Inj dur & 1.13 & $0.63-2.02$ & 0.689 & - & - & - \\
\hline Year $^{3} \times \operatorname{Inj}$ dur ${ }^{2}$ & 2.00 & $1.08-3.71$ & 0.027 & - & - & - \\
\hline Year $^{3} \times \operatorname{Inj}$ dur $^{3}$ & 1.45 & $0.85-2.46$ & 0.170 & - & - & - \\
\hline Year $^{3} \times \operatorname{Inj}$ dur ${ }^{4}$ & 0.70 & $0.52-0.94$ & 0.017 & - & - & - \\
\hline Year $^{4} \times \operatorname{Inj}$ dur & 0.88 & $0.55-1.39$ & 0.572 & - & - & - \\
\hline Year $^{4} \times \operatorname{Inj}$ dur ${ }^{2}$ & 0.76 & $0.52-1.12$ & 0.170 & - & - & - \\
\hline Year $^{4} \times \operatorname{Inj}$ dur $^{3}$ & 0.86 & $0.61-1.22$ & 0.406 & - & - & - \\
\hline Year $^{4} \times \operatorname{Inj}$ dur ${ }^{4}$ & 1.15 & $0.95-1.39$ & 0.142 & - & - & - \\
\hline \multicolumn{7}{|c|}{ Other interactions } \\
\hline Year $\times$ Age & - & - & - & 1.36 & $1.04-1.79$ & 0.027 \\
\hline Year $^{2} \times$ Age & - & - & - & 0.64 & $0.48-0.85$ & 0.002 \\
\hline Year $\times$ Female & - & - & - & 0.69 & $0.48-0.97$ & 0.032 \\
\hline
\end{tabular}

$\mathrm{Cl}$ : confidence interval; Inj dur: injection duration.

Hyphens (-) denote parameter not included for that region; e.g., Age ${ }^{2}$ appears in London only.

Odds ratios and $95 \% \mathrm{Cl}$ per standard deviation increase in explanatory variables.

Variables are scaled to have a standard deviation of 1 , and powers taken thereof $\left(x^{y}\right)$. 
Observed and modelled HIV prevalence, by cohorts of year started injecting, London $(n=6,892)$ versus the rest of England and Wales $(n=31,647), 1990-2011$.

A.London
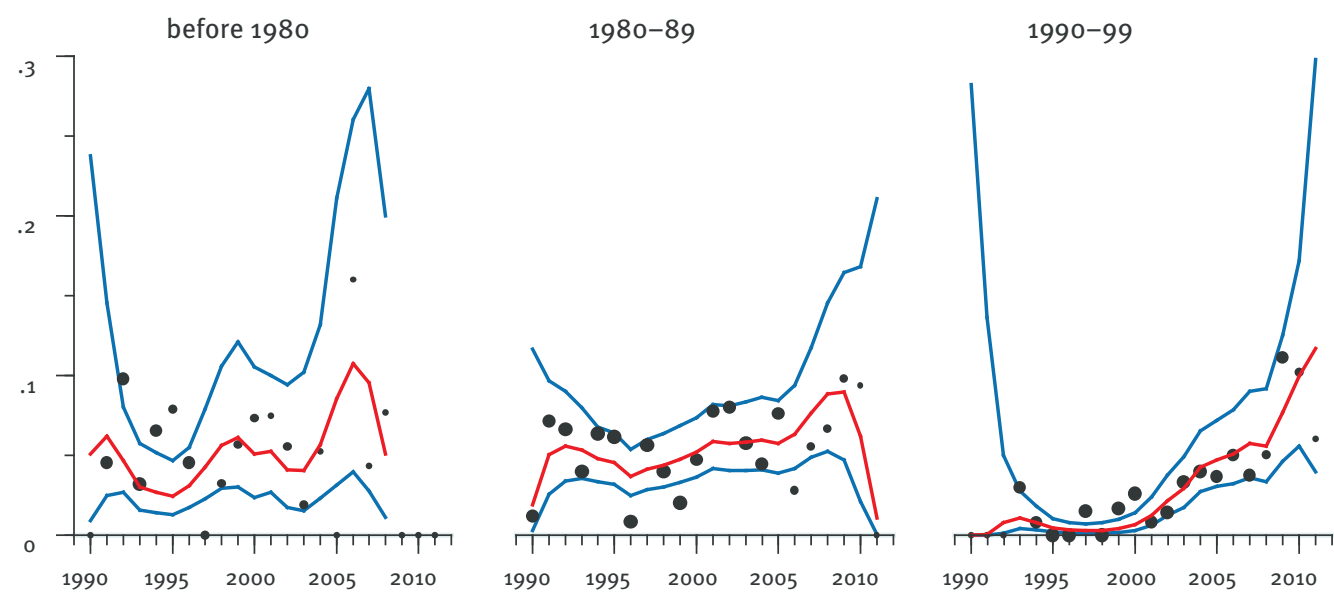

2000 onwards

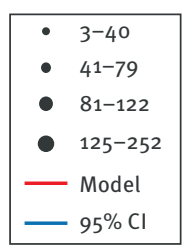

B. Rest of England and Wales

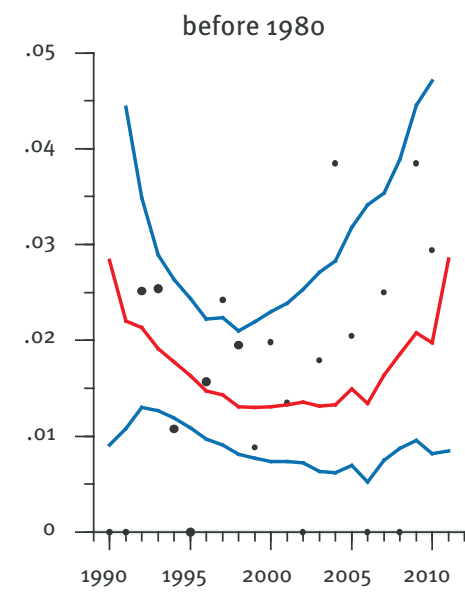

1980-89

1990-99

2000 onwards
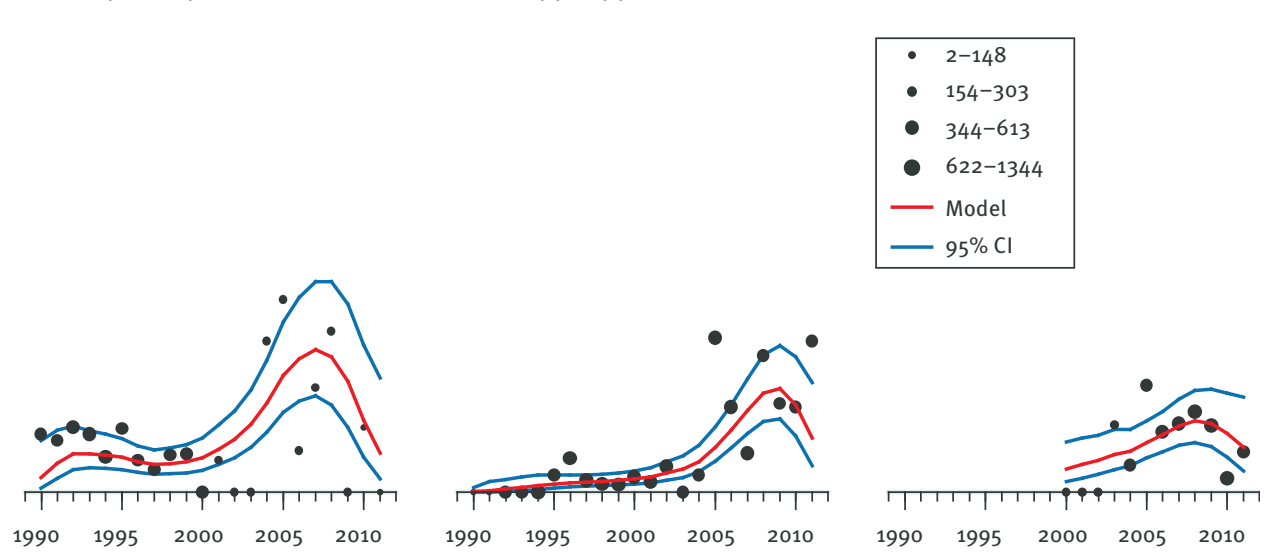

$\mathrm{Cl}$ : confidence intervals; HIV: human immunodeficiency virus.

Data points are plotted according to quartiles of sample size. Model predictions are displayed with $95 \% \mathrm{Cl}$, with estimates based on mean covariate levels for that year, hence plotted functions are not entirely smooth. Data were sparse in the pre-1980 cohorts, and some model estimates and $\mathrm{Cl}$ have been omitted due to excessive uncertainty.

The interaction between time and injecting duration means that the cohorts of PWID that started injecting at different times had different patterns of HIV prevalence throughout their injecting careers. Figure 1 shows observed and modelled HIV prevalence for London and elsewhere by 10-year cohorts of the year they started injecting. Prevalence in London was generally stable in those who began injecting before 1980 , with a peak around 2006 , but otherwise there was no discernible overall trend over the 22 years, although data are sparse. The picture was similar in those who began injecting between 1980 and 1989, although there was a slight increase over time and again a peak in the mid-2000s, tailing off in the last year. Increases over time were most dramatic in those who began injecting between 1990 and 1999, with a significant increase from around 2000. Prevalence in those who started to inject from 2000 onwards may also have increased around this period, but data are sparse. It must be noted that estimates may be unreliable for the last one to two years of data, as polynomial functions are more sensitive to random variation at the tail ends. Model-averaged results were similar for London, but with a slightly flatter shape for trends over time, and increased standard errors.

In the rest of England and Wales, those who began injecting drugs before 1980 experienced a drop in HIV prevalence during the 1990 , followed by an increase from 2005 onwards. Those who began injecting between 1980 and 1999 had relatively low prevalence throughout the 1990s, but there was a clear indication 
Specific comparisons of HIV infection by year and injecting duration, obtained from the final models, London ( $\mathrm{n}=6,892)$ versus the rest of England and Wales (n=31,647), 1990-2011.

\begin{tabular}{|c|c|c|c|c|c|}
\hline \multirow{2}{*}{$\begin{array}{l}\text { Injecting duration } \\
\text { (years) }\end{array}$} & \multicolumn{5}{|c|}{ Survey year } \\
\hline & $\begin{array}{c}1990 \\
\text { OR }(95 \% \mathrm{Cl})\end{array}$ & $\begin{array}{c}1995 \\
\text { OR }(95 \% \mathrm{Cl})\end{array}$ & $\begin{array}{l}2000 \\
\text { OR }(95 \% \mathrm{Cl})\end{array}$ & OR $\begin{array}{l}2005 \\
(95 \% \mathrm{CI})\end{array}$ & OR $\begin{array}{l}2010 \\
(95 \% \mathrm{Cl})\end{array}$ \\
\hline \multicolumn{6}{|l|}{ London } \\
\hline 1 & $\mathrm{NE}^{\mathrm{a}}$ & $1.36(0.42-4.45)$ & $0.71(0.19-2.58)$ & $5.47(1.83-16.34)$ & $3.24(0.70-15.05)$ \\
\hline 3 & $0.23(0.00-14.45)$ & $0.69(0.28-1.67)$ & $0.70(0.45-1.09)$ & $3.33(1.29-8.62)$ & $0.79(0.12-5.25)$ \\
\hline 5 & $2.17(0.27-17.08)$ & $0.88(0.39-2.00)$ & 1 (ref) & $3.56(1.40-9.03)$ & $0.59(0.07-5.02)$ \\
\hline 8 & $7.40(1.84-29.85)$ & $2.74(1.29-5.85)$ & $2.20(1.49-3.25)$ & $6.03(2.47-14.73)$ & $1.28(0.21-7.80)$ \\
\hline 15 & $8.39(1.25-56.53)$ & $16.24(6.88-38.33)$ & $10.27(4.07-25.92)$ & $14.78(6.04-36.15)$ & $20.58(7.35-57.61)$ \\
\hline \multicolumn{6}{|c|}{ Rest of England and Wales } \\
\hline 1 & $\mathrm{NE}^{\mathrm{a}}$ & $0.30(0.10-0.86)$ & $1.58(0.91-2.73)$ & $5.53(2.97-10.31)$ & $2.23(0.73-6.89)$ \\
\hline 3 & $0.07(0.01-0.57)$ & $0.46(0.21-1.01)$ & $1.16(0.92-1.46)$ & $4.10(2.62-6.41)$ & $3.47(1.44-8.35)$ \\
\hline 5 & $0.35(0.07-1.82)$ & $0.71(0.38-1.33)$ & 1 (ref) & $3.40(2.31-5.02)$ & $4.80(2.26-10.21)$ \\
\hline 8 & $2.22(0.60-8.19)$ & $1.37(0.81-2.34)$ & $1.01(0.81-1.26)$ & $3.06(2.02-4.64)$ & $6.54(3.26-13.14)$ \\
\hline 15 & $28.13(9.47-83.61)$ & $5.87(3.14-10.96)$ & $2.03(1.20-3.46)$ & $4.02(2.23-7.24)$ & $7.79(3.89-15.57)$ \\
\hline
\end{tabular}

OR: odds ratio; $\mathrm{Cl}$ : confidence interval.

a NE: Due to lack of data estimates are not reliable.

of an increased prevalence from 2000 onwards, followed by a possible decline from 2007. The picture was similar for the most recent cohort (2000 onwards) although again, the possible decline in the last few years is not certain. Model-averaged results were near identical.

Comparisons of prevalence levels by time and injecting duration were obtained from the model, shown in Table 4. Setting 2000 as the baseline year and an injecting duration of five years, prevalence was similar in 1995 in London (OR: 0.88; 95\% Cl: 0.39-2.00) and elsewhere (OR: $0.71 ; 95 \% \mathrm{Cl}: 0.38-1.33$ ) and increased in 2005 in London (OR: 3.56; 95\% Cl: 1.40-9.03) and elsewhere (OR: $3.40 ; 95 \% \mathrm{Cl}: 2.31-5.02)$ before falling again in London in 2010 (OR: 0.59; 95\% Cl: 0.07-5.02) but remaining elevated elsewhere (OR: 4.80; $95 \% \mathrm{Cl}$ : 2.26-10.21). It needs to be noted that the estimation was more uncertain for the recent years.

\section{Incidence}

The estimated effect of injecting duration, $h_{A}(a)$, is shown in Figure 2. There was a sharp decrease in risk after the first year of injecting before the risk rose in the fourth year and then declined over time with small peaks (e.g. at 10 and 15 years). This shape may be partly due to recall bias of age at first injection and the limitations of calculating injecting duration from current age minus age at first injection.

Trends over time for HIV and HCV are displayed in Figure 2. Results show a peak in HIV incidence in the mid-1980s followed by a decline, which was seen in both regions. The incidence for the rest of England and Wales then declined to low levels, while the incidence in London continued at a reduced, if fluctuating, rate throughout the 1990s. Both regions saw an increase from 2000 onwards, with a possible recent decline in the rest of England and Wales. Trends in HCV followed a similar pattern, but with some notable differences. There was a peak in incidence in the 1980 s followed by a slight decrease and stabilisation in London, and by a continuous decline in the rest of England and Wales. The incidence then increased in both regions over the last 10 years. However, the increase around 2005 in the rest of England and Wales was less marked for HCV than for HIV.

\section{Discussion}

Our analyses indicate that HIV prevalence among PWID in England and Wales has increased since 2000. This increase has occurred both in London and elsewhere. Prior to 2000, prevalence had been stable and probably fell in the early 1990s. These variations in prevalence would appear to be products of two periods of elevated HIV incidence among PWID. The first of these was in the early 1980 s, before the initial public health responses to the HIV epidemic. The second peak occurred in the mid-200os, with increases in new HIV infections focused outside London. This second increase was preceded by a sharp rise in reported needle and syringe sharing, which rose from $17 \%$ in 1997 to $33 \%$ in 2000 , Since then, the level has fallen slowly and was $17 \%$ in 2011 [23].

Markers of other, more common, infections also serve as an indicator of the changing overall exposure risks for HIV. HCV prevalence shows a similar pattern over time to HIV with the prevalence declining in the 1990 , followed by a rise since 2000 [17]. Our analysis 


\section{FIGURE 2}

Predicted annual incidence rates of HIV and HCV for those injecting drugs for one compared with seven years, London $(n=6,892)$ versus the rest of England and Wales $(n=31,647), 1990-2011$.

A. Temporal trends, London

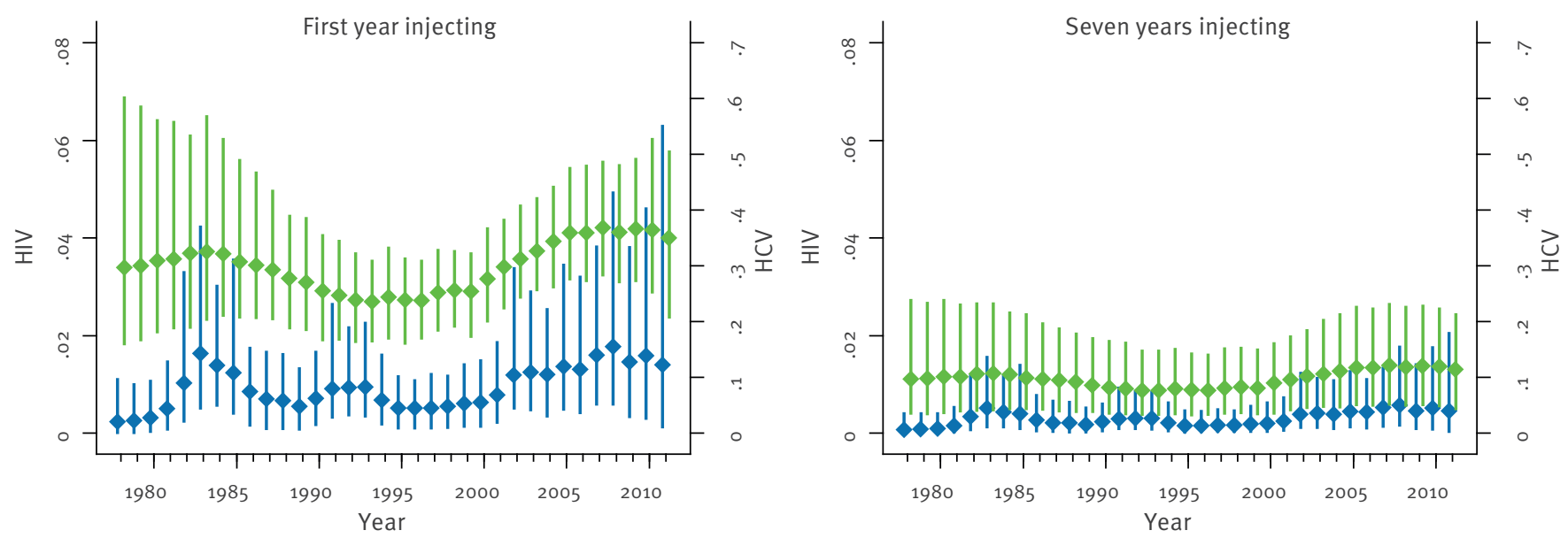

B. Temporal trends, rest of England and Wales

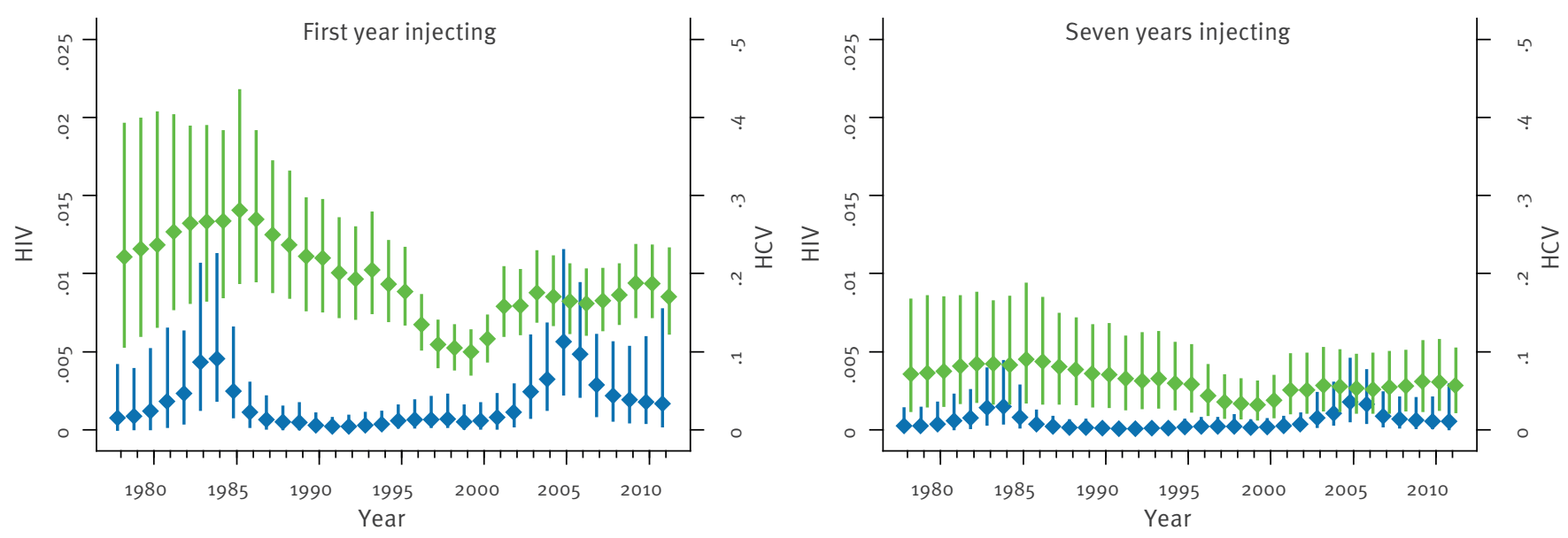

C. Injecting duration, relative risk vs year 1

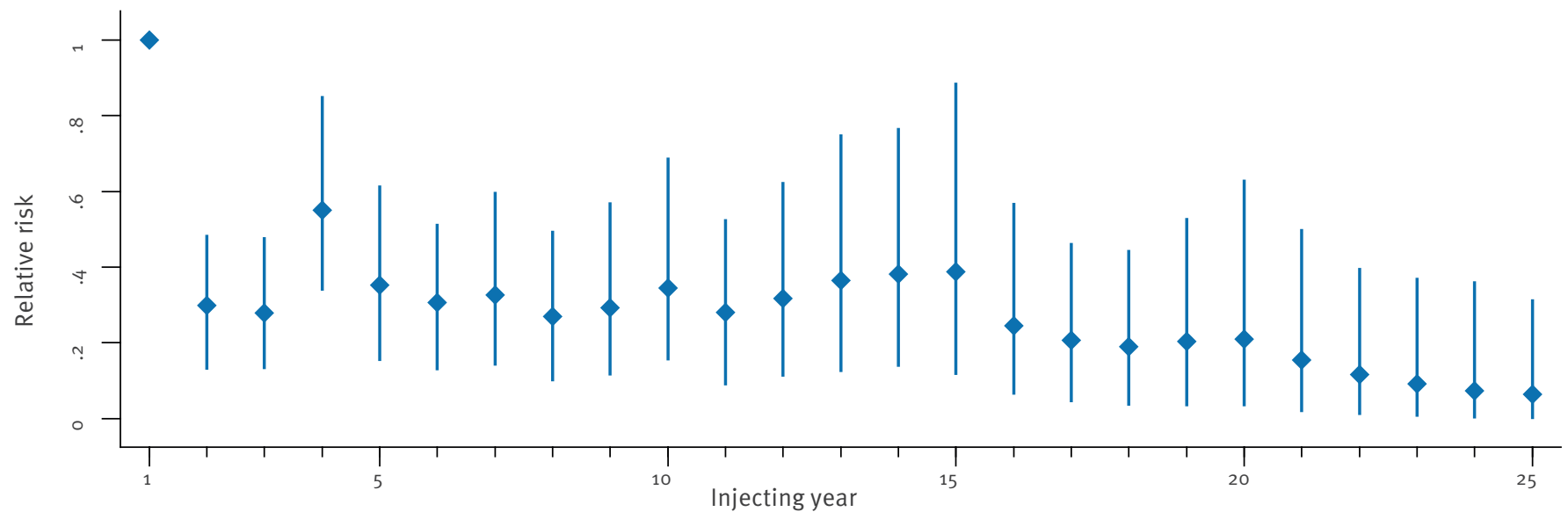

HCV: hepatitis C virus; HIV: human immunodeficiency virus

Blue: HIV; green: HCV.

Bottom panel: relative risk of infection in subsequent years vs first year of injecting. Point estimates and $95 \%$ credible intervals. 
indicates that incidences of HCV and HIV have followed similar patterns. The transmission of hepatitis $B$ virus (HBV) has continued among PWID in 2000 s despite increased vaccine coverage [24], and bacterial infections have also been a significant problem $[25,26]$.

There have been many shifts in policy related to bloodborne viruses (BBVs) among PWID since the middle of 1980 s (Table 1). While it is not possible from a simple temporal comparison to establish any direct impact of policy changes on HIV prevalence or incidence, there do seem to be some temporal alignments. From the mid-1980s until well into the 1990s, HIV was a major focus of policy in the UK, with national expansion of both OST and NSP provision [27-29], and the 1992 National Health Strategy introduced a target to reduce needle/syringe sharing [30]. Estimated incidence of HIV declined during the mid-1980s and generally remained low, resulting in a decrease in observed HIV prevalence in the early 1990s. Reported needle/syringe sharing was also stable in the mid-1990s, but the proportion of individuals that reported sharing in the preceding month then increased from around 1998.

In 1998, there was a shift in policy [31]. Since then reducing risks of HIV infection through IDU has not been a target. The 1998 UK Drug Strategy focused on reducing crime and social harms [32] and only peripherally mentioned BBVs [30]. This was perhaps not unreasonable given the low level of HIV and the comparatively low HCV prevalence at that time [33,34]. The National HIV and Sexual Health Strategy launched in 2001 was focused principally on sexual transmission, and IDU was only briefly mentioned [35]. Neither was preventing BBVs prominent in the 2002 National Framework for Drug Treatment Services in England [36], nor in the Revised Drug Strategy [37].

This policy shift occurred at a time when sharing was rising and risky injection practices were becoming more common $[12,38,39]$. It is likely that the overall prevalence of IDU was also increasing at this time [40]; and there was also a rise in injection frequency due to increased crack-cocaine use (usually in combination with heroin) [41]. Together these may have resulted in a decline in the coverage of NSPs [42]. On the other hand, this may have, in part, been mitigated by a further expansion in the provision of OST and addiction treatment from the early 2000s [43]. However, during this period other infections increased among PWID [44].

When the National Framework for Drug Treatment Services in England was revised in 2006, harm reduction measures were more prominent [45] and a drug related harm action plan, focusing on BBVs and overdose, was launched in 2007 [46], although BBV prevention remained peripheral in the updated drug strategy of 2008 [47]. However, in 2008 a national harm reduction awareness campaign was launched [48], six years after the increase in needle and syringe sharing was reported [12]. These and other recent measures to reinvigorate harm reduction [49] may help sustain the recent fall in incidence and may lead to a future reduction in prevalence. Arguably these actions could have been implemented sooner, in response to the reported increases in sharing [12], hepatitis C prevalence [44], and bacterial infections $[50,44]$. It is unclear whether prompt action may have reduced, or even possibly prevented, the rise in HIV infections from 2000 onwards, but these findings indicate that policy needs to adapt quickly in response to the changing risks in this population.

A new drugs strategy was launched in 2010 [51], which briefly mentioned BBVs and saw their prevention as part of the new emphasis on recovery-focused addiction treatment. Continued monitoring of HIV prevalence among PWID through the survey will permit us to assess whether the recent drop in incidence is sustained.

It is important to consider the limitations of our analysis. Firstly, although this study aimed to examine temporal changes in HIV prevalence in detail, analysis was constrained by relatively low prevalence. There is always a trade-off between fitting a flexible model and the danger of over-fitting, and we have tried to balance these and assess the robustness of our conclusions by using model-averaging techniques. We considered a rich array of possible models that could capture complexities of the data, using an objective function, i.e. AIC, for model selection and weighting. Models incorporating cubic splines, which can be fitted to an arbitrarily complex pattern [52], were also examined extensively but not found to offer significant improvement.

Estimation of incidence required the joint modelling of BBV infection risk by injecting duration, assuming people infected with BBVs are likely to exhibit the same risky behaviour as HIV- and HCV-infected individuals. This may be reasonable where HIV infection in peers is unknown, but does not account for the possibility that PWIDs may behave differently with regard to known HIV infections than to known HCV infections, with HCV infection perceived by some PWIDs as being inevitable [53]. We were also unable to account for sexual transmission of HIV and infection before starting to inject, which could potentially alter our conclusions regarding timing of infection and the risk attributable to injecting. There may also have been some misclassification in relation to the period of exposure, as current age minus age at first injection was used to derive this. The joint estimation of disease incidence is not new; for instance, force of infection for HBV and HCV have been estimated jointly via shared frailty models [54]. Other studies have demonstrated that there is a threshold effect if HCV prevalence is above certain levels, indicating a level of risk behaviour that allows HIV to spread [55]. This threshold is lower if there is heterogeneity in risk [56], and such heterogeneity may also influence apparent patterns in risk according to 
injecting duration [57]. Further investigation of injecting risk patterns and changes over time that makes use of data on multiple infections is certainly warranted.

Finally, it is important to consider the generalisability of these findings. The comparative rarity, marginalisation, and illicit nature of IDU all impede the construction of a sampling frame, making the representativeness of our sample of PWID impossible to measure. This study aimed to minimise sampling biases by using data from an established survey that consistently applied the same recruitment approach over the 22-year period. Studies which have recruited PWID from community settings, i.e. not through services, in England and Wales have found very few individuals who are not, or have not recently been, in contact with the types of service used for recruitment here [58]. Even so, caution is needed when attempting to generalise these findings to all PWID in England and Wales.

In conclusion, the incidence and prevalence of HIV among PWID in England and Wales have varied markedly over time, with two peaks in estimated incidence. While it is not possible to ascribe these changes in incidence unequivocally to policy changes, there would appear to be a broad temporal alignment. This finding suggests that there is a need for particular vigilance when changes are made in policy related to PWID. It is also important for these policies to be reviewed regularly to ensure a rapid and robust response to signs of increased infection risk.

\section{Acknowledgments}

We are grateful to all of the people who injected drugs for agreeing to take part in the survey and to the various services across England and Wales who assisted with their recruitment. We would like to thank the many staff who have worked on the survey and have undertaken the laboratory work. The survey is undertaken by the Health Protection Agency (now part of Public Health England) which is funded through the Department of Health.

\section{Conflicts of interest}

None declared.

\section{Authors' contributions}

All authors contributed to the writing of the paper; with writing co-ordinated by $\mathrm{VH}$, and statistical analyses led by $\mathrm{RH}$ and overseen by DA. The ongoing survey is managed by $\mathrm{VH}$ and overseen by FN. AM and SC have assisted with the running of the survey, with AM extracting the data used in the analysis and SC assisting with the assembly of policy time line. Development of the laboratory tests and processes employed was led by JP, who managed their application to this study.

\section{References}

1. Des Jarlais DC, Friedman SR, Choopanya K Vanichseni S, Ward TP. International epidemiology of HIV and AIDS among injecting drug users. AIDS. 1992;6(10):1053-68. http://dx.doi. org/10.1097/00002030-199210000-00001

2. Ghys PD, Bazant W, Monteiro MG, Calvani S, Lazzari $\mathrm{S}$. The epidemics of injecting drug use and HIV in Asia. AIDS. 2001:15(Suppl 5):S91-9 http://dx.doi. org/10.1097/00002030-200100005-00012

3. Rhodes T, Lowndes C, Judd A, Mikhailova LA, Sarang A, Rylkov A, et al. Explosive spread and high prevalence of HIV infection among injecting drug users in Togliatti City, Russian Federation: Implications for HIV prevention. AIDS. 2002;16(13):F25-31. http://dx.doi. org/10.1097/00002030-200209060-00002

4. Aceijas C, Stimson GV, Hickman M, Rhodes T; United Nations Reference Group on HIV/AIDS Prevention and Care among IDU in Developing and Transitional Countries. Global overview of injecting drug use and HIV infection among injecting drug users. AIDS. 2004;18(17):2295-303. http://dx.doi. org/10.1097/00002030-200411190-00010

5. Van Ameijden, Coutinho RA. Maximum impact of HIV prevention measures targeted at injecting drug users. AIDS. 1998;12(6):625-33. http://dx.doi. org/10.1097/00002030-199806000-00012

6. MacDonald M, Wodak AD, Ali R, Crofts N, Cunningham $\mathrm{PH}$, Dolan K, et al. HIV prevalence and risk behaviours in needle exchange attenders: a national study. Med J Aust. 1997;166(5):237-40.

7. Crofts A, Aitken CK. Incidence of blood borne virus infection and risk behaviours in a cohort of injecting drug users in Victoria. Med J Aust. 1997;167(1):17-20.

8. Hurley SF, Jolley DJ, Kaldor IM. Effectiveness of needleexchange programmes for prevention of HIV infection. Lancet. 1997;349(9068):1797-800. http://dx.doi.org/10.1016/ So140-6736(96)11380-5

9. Stimson GV. AIDS and injecting drug use in the United Kingdom, 1987-1993: The policy response and the prevention of the epidemic. Soc Sci Med. 1995;41(5):699-716. http:// dx.doi.org/10.1016/0277-9536(94)00435-V

10. Robertson JR, Bucknall AB, Welsby PD, Roberts JJ, Inglis JM, Peutherer JF, et al. Epidemic of AIDS related virus (HTLVIII/LAV) infection among intravenous drug abusers. $\mathrm{Br}$ Med J. 1986;292(6519):527-9. http://dx.doi.org/10.1136/ bmj.292.6519.527

11. Hope VD, Judd A, Hickman M, Sutton A, Stimson GV, Parry JV, et al. HIV prevalence among Injecting Drug Users in England \& Wales 1990 to 2003: Evidence for increased transmission in recent years. AIDS. 2005;19(11):1207-14. http://dx.doi. org/10.1097/01.aids.0000176222.71355.a1

12. Hope VD, PA Rogers, L Jordan, T Paine, S Barnett, JV Parry, et al. Sustained increase in the sharing of needles and syringes among drug users in England and Wales. AIDS. 2002;16(18):2494-6. http://dx.doi. org/10.1097/00002030-200212060-00022

13. Judd A, Hickman M, Jones S, McDonald T, Parry JV, Stimson $\mathrm{GV}$, et al. Incidence of hepatitis $\mathrm{C}$ virus and HIV among new injecting drug users in London - prospective cohort study. BMJ. 2005;330(7481):24-5. http://dx.doi.org/10.1136/ bmj.38286.841227.7C

14. Noone A, Durante AJ, Brady AR, Majid F, Swan AV, Parry JV, et al. HIV infection in injecting drug users attending centres in England and Wales, 1990-1991. AIDS. 1993;7(11):1501-7. http:// dx.doi.org/10.1097/00002030-199311000-00015

15. Judd A, Parry J, Hickman M, McDonald T, Jordan L, Lewis K, et al. Evaluation of a modified commercial assay in detecting antibody to hepatitis C virus in oral fluids and dried blood spots. J Med Virol. 2003;71(1):49-55. http://dx.doi.org/10.1002/ jmv.10463

16. Connell JA, Parry JV, Mortimer PP, Duncan J. Novel assay for the detection of immunoglobulin $\mathrm{G}$ anti-human immunodeficiency virus in untreated saliva and urine. J Med Virol. 1993;41(2):15964. http://dx.doi.org/10.1002/jmv.1890410212

17. Davies C, English L, Lodwick A, McVeigh J, Bellis MA, editors. UK Focal Point on Drugs. United Kingdom Drug Situation: Annual Report to the European Monitoring Centre for Drugs and Drug Addiction (EMCDDA) 2009. Chapter 13. ISSN 1609-6150. London: Department of Health; October 2009. Available from: http://www.nta.nhs.uk/uploads/2009.pdf

18. Sweeting MJ, Hope VD, Hickman M, Parry JV, Ncube F, Ramsay $M E$, et al. Hepatitis $C$ infection among injecting drug users in England and Wales (1992-2006): there and back again? Am J Epidemiol. 2009;170(3):352-6o. http://dx.doi.org/10.1093/aje/ kwp141

19. Burnham KP, Anderson DR. Formal inference from more than one model: multimodel inference (MMI). In: Model selection and multimodel inference: A practical information theoretic approach. 2nd ed. New York: Springer-Verlag; 2002. p.149-205. ISBN 0-387-95364-7. 
20. Keiding N. Age specific incidence and prevalence: a statistical perspective (with discussion). J R Statist Soc A. 1991;154(3):371-412. http://dx.doi.org/10.2307/2983150

21. Ades AE, Nokes DJ. Modeling age- and time-specific incidence from seroprevalence: toxoplasmosis. Am J Epidemiol. 1993; 137(9):1022-34.

22. Welton NJ, Ades AE. A model of toxoplasmosis incidence in the UK: evidence synthesis and consistency of evidence. J R Statist Soc C. 2005;54(2):385-404. http://dx.doi. org/10.1111/j.1467-9876.2005.00490.x

23. Health Protection Agency (HPA), Health Protection Scotland, Public Health Wales, and Public Health Agency Northern Ireland. Shooting Up: Infections among people who inject drugs in the UK 2011. An update: November 2012. London: HPA; 2012. Available from: http://www.hpa.org.uk/ Publications/InfectiousDiseases/BloodBornelnfections/ ShootingUp/1211Shootingup2012/

24. Judd A, Hickman M, Hope VD, Sutton AJ, Stimson GV, Gill ON, et al..Impact of twenty years of selective hepatitis $B$ vaccination: is hepatitis $B$ declining among injecting drug users in England and Wales? J Viral Hepat. 2007;14(8):584-91. http://dx.doi. org $/ 10.1111 / j .1365-2893.2007 .00844 . x$

25. Jones JA, Salmon JE, Djuretic T, Nichols G, George RC, Gill ON, on behalf of an investigating team. An outbreak of serious illness and death among injecting drug users in England and Wales during 2000. J Med Microbiol. 2002;51(11):978-84.

26. Health Protection Agency (HPA), Health Protection Scotland, National Public Health Service for Wales, CDSC Northern Ireland, CRDHB, and the UASSG. Shooting Up - Infections among injecting drug users in the United Kingdom 2005 - An update: October 2006. London: HPA; 2006. ISBN o 901144 86 X. Available from: http://www.hpa.org.uk/Publications/ InfectiousDiseases/BloodBornelnfections/ShootingUp/o610Sh ootingUpInfectionsamongIDUs2005/

27. Advisory Council on the Misuse of Drugs. AIDS and drug misuse. Part 1 .London: Department of Health; 1988.

28. Evaluation of syringe exchange schemes. Circular EL(89) P/81. London: Department of Health; 1989.

29. Tackling drugs together. A strategy for England 1995-1998. London: Stationery Office; 1995.

30. Secretary of State for Health. The Health of the Nation: strategy for health in England. London: Stationery Office; 1992.

31. Stimson GV. 'Blair declares war': the unhealthy state of British drug policy. Int J Drug Policy. 2000;11(4):259-264. http:// dx.doi.org/10.1016/S0955-3959(00)00060-8

32. The United Kingdom Anti-Drugs Co-ordinator. Tackling drugs to build a better Britain: the governments ten-year strategy for tackling drug misuse. London: Stationery Office; 1998.

33. Unlinked Anonymous Surveys Steering Group. Prevalence of HIV in the United Kingdom 1998: data to the end of 1998. London: Department of Health; 1999.

34. Hope VD, Judd A, Hickman M, Lamagni T, Hunter G, Stimson GV, et al. Prevalence of hepatitis $C$ virus in current injecting drug users in England and Wales: is harm reduction working? Am J Public Health. 2001;91(1):38-42. http://dx.doi.org/10.2105/ AJPH.91.1.38

35. Better prevention, better services, better sexual health The national strategy for sexual health and HIV. London: Department of Health; 2001 . Available from: http:// webarchive.nationalarchives.gov.uk/20130107105354/http:// www.dh.gov.uk/en/Publicationsandstatistics/Publications/ PublicationsPolicyAndGuidance/DH_4003133

36. Models of care for the treatment of drug misusers. London: National Treatment Agency for Substance Misuse; 2002. ISBN 0-9544534-0-9. Available from: http://www.nta.nhs.uk/ uploads/nta_modelsofcare2_2002_moc2.pdf

37. Update Drugs Strategy. London: Home Office; 2002. ISBN 1-84082-9397.

38. Hickman M, Hope VD, Brady T, Madden P, Jones S, Honour S, et al. Hepatitis C (HCV) prevalence, and injecting risk behaviour in multiple sites in England in 2004. J Viral Hepat. 2007;14(9):645-52. http://dx.doi. org/10.1111/j.1365-2893.2007.00855.x

39. Rhodes T, Briggs D, Kimber J, Holloway G, Jones S. Groin injecting and vein care in the context of crack and 'speedball' injection: Qualitative study. Addiction. 2007;102(11):1782-90. http://dx.doi.org/10.1111/j.1360-0443.2007.01969.x

40. De Angelis D, Hickman M, Yang S. Estimating long-term trends in the incidence and prevalence of opiate/injecting drug use and the number of ex-users: the use of back-calculation methods and opiate overdose deaths. Am J Epidemiol. 2004;16o(10):994-1004. http://dx.doi.org/10.1093/aje/kwh306

41. Hope VD, Hickman M, Tilling K. Capturing crack-cocaine use: Estimating the prevalence of Crack-cocaine use in London using capture-recapture with covariates. Addiction, 2005:100(11):1701-8. http://dx.doi.

org/10.1111/j.1360-0443.2005.01244.x

42. Hickman M, Higgins V, Hope VD, Bellis M, Tilling K, Walker A, et al. Injecting drug use in Brighton, Liverpool, and London: best estimates of prevalence and coverage of public health indicators. J Epidemiol Community Health. 2004;58(9):766-71. http://dx.doi.org/10.1136/jech.2003.015164

43. Statistics for drug treatment activity in England 2005/06 from the National Drug Treatment Monitoring System. London: National Treatment Agency for Substance Misuse; 2006. Available from: https://www.ndtms.net/Reports.aspx (permissions required).

44. Health Protection Agency (HPA), SCIEH, National Public Health Service for Wales, CDSC Northern Ireland, CRDHB, and the UASSG. Shooting Up - Infections among injecting drug users in the United Kingdom 2002 - An update: December 2003. London: HPA; 2003 . ISBN o 90114462 2. Available from: http://www.hpa.org.uk/Publications/InfectiousDiseases/ BloodBornelnfections/ShootingUp/0312ShootingUpInfectionsa mongdrugusers/

45. Models of care for the treatment of adult drug misusers: Update 2006. London: National Treatment Agency for Substance Misuse; 2006. MOC 3 . Available from: www.nta.nhs. uk/uploads/nta_modelsofcare_update_2006_moc3.pdf

46. Reducing drug-related harm: An action plan. London: Department of Health; 2007. Available from: http:// webarchive.nationalarchives.gov.uk/20080910134953/ dh.gov.uk/en/Publicationsandstatistics/Publications/ PublicationsPolicyAndGuidance/DH_074850

47. Drugs: protecting families and communities: The 2008 drug strategy. London: HM Government; 2008. ISBN 978-1-84726615-3. Available from: http://webarchive.nationalarchives. gov.uk/20100419081707/http:/drugs.homeoffice.gov.uk/ publication-search/drug-strategy/drug-strategy-2008

48. Harm Reduction Works. London: National Treatment Agency for Substance Misuse. [Accessed: 27 Mar 2014]. Available from: http://www.harmreductionworks.org.uk/

49. Needle and syringe programmes: providing people who inject drugs with injecting equipment. Public Health Guidance, $\mathrm{PH} 18$. London: National Institute for Health and Care Excellence (NICE); 2009. Available from: http://guidance.nice.org.uk/PH18

50. Methicillin resistant Staphylococcus aureus (MRSA) in injecting drug users. CDR Weekly. 2003;13(27). 3 Jul 2003. Available from: http://webarchive.nationalarchives.gov.uk/+/http:// www.hpa.org.uk/cdr/archives/2003/cdr2703.pdf

51. Drug strategy 2010. Reducing demand, restricting supply, building recovery: supporting people to live a drug free life. London: HM Government; 2010. ISBN: 978-1-84987388-8. Available from: https://www.gov.uk/government/ uploads/system/uploads/attachment_data/file/98026/drugstrategy-2010.pdf

52. Royston P. A strategy for modelling the effect of a continuous covariate in medicine and epidemiology. Stat Med. 2000;19(14):1831-47. http://dx.doi.org/10.1002/1097 0258(20000730)19:14《1831::AID-SIM502〉3.0.CO;2-1

53. Rhodes T, Davis M, Judd A. Hepatitis $C$ and its risk management among drug injectors in London: renewing harm reduction in the context of uncertainty. Addiction. 2004;99(5):621-33. http://dx.doi.org/10.1111/j.1360-0443.2004.00692.x

54. Sutton AJ, Gay NJ, Edmunds WJ, Hope VD, Gill ON, Hickman M. Modelling the force of infection for hepatitis B and hepatitis $C$ in injecting drug users in England and Wales. BMC Infect Dis. 2006;6:93. http://dx.doi.org/10.1186/1471-2334-6-93

55. Vickerman P, Hickman M, May M, Kretzschmar M, Wiessing L. Can hepatitis $C$ virus prevalence be used as a measure of injection-related human immunodeficiency virus risk in populations of injecting drug users? An ecological analysis. Addiction. 2010;105(2):311-8. http://dx.doi. org/10.1111/j.1360-0443.2009.02759.x

56. de Vos AS, van der Helm JJ, Prins M, Kretzschmar ME. Determinants of persistent spread of HIV in HCV-infected populations of injecting drug users. Epidemics. 2012;4(2):5767. http://dx.doi.org/10.1016/j.epidem.2012.01.001

57. Sanchez AY, Aerts M, Shkedy Z, Vickerman P, Faggiano F, Salamina G, et al. A mathematical model for HIV and hepatitis $C$ co-infection and its assessment from a statistical perspective, Epidemics. 2013;5(1):56-66. http://dx.doi. org/10.1016/j.epidem.2013.01.002

58. M Hickman, Hope V, Brady T, Madden P, Jones S, Honor S, et al. Hepatitis C (HCV) prevalence, and injecting risk behaviour in multiple sites in England in 2004. J Viral Hepat. 2007;14(9):645-52. http://dx.doi. org/10.1111/j.1365-2893.2007.00855.x 
59. Center for Disease Control (CDC). Pneumocystis pneumonia-Los Angeles. MMWR Morb Mortal Wkly Rep. 1981;30(21):250-2.

60. Health Protection Agency. HIV in the United Kingdom: 2011 Report. London: Health Protection Services, Colindale; 2011. Available from: http://www.hpa.org.uk/webc/hpawebfile/ hpaweb_c/1317131685847

61. Barre-Sinoussi F, Chermann JC, Rey F, Nugeyre HT, Chamaret $\mathrm{S}$, Gruest J, et al. Isolation of a T-lymphotropic retrovirus from a patient at risk for acquired immune deficiency syndrome (AIDS). Science. 1983;220(4599);868-71. http://dx.doi. org/10.1126/science.6189183

62. Sarngadharan MG, Popovic M, Brunch L, Schupbach J, Gallo RC. Antibodies reactive with human T-lymphotropic retroviruses (HTLV-III) in the serum of patients with AIDS. Science. 1984;224(4648):506-8. http://dx.doi.org/10.1126/ science.6324345

63. Cheingsong-Popov R, Weiss RA, Dalgleish A, Tedder RS Shanson DC, Jeffries DJ, et al. Prevalence of antibody to human T-lymphotropic virus type III in AIDS and AIDS-risk patients in Britain. Lancet. 1984;2(8401):477-80. http://dx.doi. org/10.1016/S0140-6736(84)92562-5

64. Mortimer PP, Jesson WJ, Vandervelde EM, Pereira MS. Prevalence of antibody to human T lymphotropic virus type III by risk group and area, United Kingdom 1978-84. Br Med J (Clin Res Ed). 1985;290(6476):1176-8. http://dx.doi.org/10.1136/ bmj.290.6476.1176

65. Mortimer PP, Parry JV, Mortimer JY. Which anti-HTLV III/ LAV assays for screening and confirmatory testing? Lancet. $1985 ; 2(8460): 873-7$. http://dx.doi.org/10.1016/S0140-6736(85)90136-9

66. Yarchoan R, Klecker RW, Weinhold KJ, Markham PD, Lyerly HK, Durack DT, et al. Administration of 3'-azido-3'-deoxythymidine, an inhibitor of HTLV-III/LAV replication, to patients with AIDS or AIDS-related complex. Lancet. 1986;1(8481):575-80. http:// dx.doi.org/10.1016/S0140-6736(86)92808-4

67. AIDS (Control) Act 1987. London: Stationery Office; 1987. ISBN o 10543387 X. Available from: http://www.legislation.gov.uk/ ukpga/1987/33/enacted

68. Parry JV, Perry KR, Mortimer PP. Sensitive assays for viral antibodies in saliva: an alternative to tests on serum. Lancet. 1987;2(8550):72-5. http://dx.doi.org/10.1016/S0140-6736(87)92737-1

69. Advisory Council on the Misuse of Drugs. AIDS and drug misuse update. London: Stationery Office; 1993.

70. Majid A, Holmes R, Desselberger U, Simmonds P, McKee TA. Molecular epidemiology of hepatitis $C$ virus infection amongst intravenous drug users in rural communities. J Med Virol. 1995;46(1):48-51. http://dx.doi.org/10.1002/jmv.1890460111

71. Cooper DA and Merigan TC. Clinical treatment. AIDS. 1996;10(Suppl A):S133-4. http://dx.doi.org/10.1097/00002030-199601001-00018

72. Unlinked Anonymous Surveys Steering Group. Prevalence of HIV in England and Wales, data to the end of 1996. London: Department of Health, Public Health Laboratory Service, Institute of child health; 1997.

73. Tackling drugs to build a better Britain: The government's ten-year strategy for tackling drug misuse. London: Department of Health; 1998. Available from: http:// webarchive.nationalarchives.gov.uk/+/www.dh.gov. uk/en/Publicationsandstatistics/Publications/ PublicationsPolicyAndGuidance/DH_4006530

74. Tackling crack: a vational plan. London: Home Office; 2002. Available from: http://www.drugscope.org.uk/ Resources/Drugscope/Documents/PDF/Good\%2oPractice/ NationalCrackPlan.pdf

75. Tackling substance misuse in Wales - a partnership approach. Cardiff: National Assembly for Wales; 2000. ISBN 075042438 9.

76. National Treatment Agency for Substance Misuse (NTA). London: Home Office. [Accessed: 27 Mar 2014]. Available from: http://webarchive.nationalarchives.gov.uk/20100407120701/ drugs.homeoffice.gov.uk/treatment/strategy/nta/

77. Hepatitis C action plan for England. London: Department of Health; 2004 Available from: http://webarchive. nationalarchives.gov.uk/20130107105354/http://dh.gov. uk/prod_consum_dh/groups/dh_digitalassets/@dh/@en/ documents/digitalasset/dh_4084713.pdf 